\title{
Riverbank Filtration: A Sustainable Process to Attenuate Contaminants during Drinking Water Production
}

\author{
Pradeep Kumar $^{* 1}$, Indu Mehrotra ${ }^{2}$, Ankush Gupta ${ }^{3}$, Soma Kumari ${ }^{4}$ \\ ${ }^{1}$ Department of Civil Engineering, Indian Institute of Technology, Roorkee, Uttarakhand 247667, India \\ e-mail: pkumafce@iitr.ac.in \\ ${ }^{2}$ Department of Civil Engineering, Indian Institute of Technology, Roorkee, Uttarakhand 247667, India \\ e-mail: imehrotra46@gmail.com \\ ${ }^{3}$ Department of Civil Engineering, Indian Institute of Technology, Roorkee, Uttarakhand 247667, India \\ e-mail: ag343@ cornell.edu \\ ${ }^{4}$ Department of Civil Engineering, Indian Institute of Technology, Roorkee, Uttarakhand 247667, India \\ e-mail: soma.iitr12@gmail.com
}

Cite as: Kumar, P., Mehrotra, I., Gupta, A., Kumari, S., Riverbank Filtration: A Sustainable Process to Attenuate Contaminants during Drinking Water Production, J. sustain. dev. energy water environ. syst., 6(1), pp 150-161, 2018, DOI: https://doi.org/10.13044/j.sdewes.d5.0176

\begin{abstract}
Riverbank filtration leads to purification of water. For India it can be a simple, economical and effective alternative. A few unanswered questions were: Can it work in Indian mountainous regions? Will it be of any advantage in the case of some of the polluted Indian surface waters? With the goal to evaluate use of riverbank filtration as a sustainable technology under widely varying conditions prevalent in India, the effectiveness of riverbank filtration has been examined over the last 10 years. In the case of cleaner surface waters, the wells deliver water free of turbidity and coliform even during monsoon irrespective of well configuration. In the case of polluted source waters, it results in an overall advantage in terms of improved raw water quality, reduced degree and cost of subsequent treatment and decreased levels of disinfection by-products. The study shows riverbank filtration to be an effective and sustainable option for plains as well as the mountainous region.
\end{abstract}

\section{KEYWORDS}

Riverbank filtration, Lakebank filtration, Water quality, Drinking water, Coliforms, Production wells, Surface water, Ground water.

\section{INTRODUCTION}

Any process close to nature is expected to be sustainable. Interestingly, there are several basic processes in nature, which lead to continuous purification of water. One of them is the subsurface passage of water through the sand and gravel on the banks of rivers and lakes that leads to natural purification of surface water. This process is known as Riverbank Filtration (RBF) or simply Bank Filtration (BF, a unified term for both river and lake bank/bed filtration, $\mathrm{RBF} / \mathrm{LBF}$ ) [1]. Scientific investigations into this process have revealed that passage of water through aquifer material leads to the removal of turbidity, dissolved organics, giardia, cryptosporidium, e-coli, viruses, etc. [2]. Passage

\footnotetext{
* Corresponding author
} 
of water through natural bank materials also changes the concentration of inorganic ions. In some cases, filtrate requires further treatment while at several places it is so good that even disinfection is not necessary [3].

During infiltration and passage through the aquifer, a combination of processes such as filtration, microbial degradation at the interface, adsorption onto the aquifer material and dilution with background groundwater etc., attenuate water-borne contaminants [4]. RBF has been in use in waterworks since early $19^{\text {th }}$ century in UK and Germany. In Europe, it provides drinking water to cities like Dusseldorf, Berlin, Dresden, Amsterdam, Zürich, Bratislava, Budapest, etc. [5]. In European cities, RBF systems have been designed for travel times of several weeks or even months with the objective of attenuating even the dissolved organics, pathogens and trace micro organics, etc. The focus has been on getting filtrate quality, which requires no treatment, i.e. considering it as complete treatment and not just a pre-treatment step.

Implementation of bank filtration in various real-life situations depends on several factors such as pollutant load in the water body, the characteristics of bank materials (amount of sand, clays, gravels, stones and its profile), the distance and depth of the water abstraction device, rate at which water is abstracted, seasonal variations in rain and water levels, local geology and groundwater flow in the region. The efficiency of bank filtration process is site specific. Accordingly, $\mathrm{RBF} / \mathrm{LBF}$ as practiced in Europe and North America can't be directly adopted in India. Although RBF/LBF systems existed in plains in India, however, no research publications were available till 2005. A need was felt to study existing/upcoming RBF/LBF systems in terms of hydrogeology, water quality, etc. with an idea to gain and strengthen knowledge, and bring it to practice in place of direct collection of surface waters. In the developing world, particularly in small cities, operation and maintenance of water treatment plants is a challenge due to non-availability of skilled manpower and electricity. $\mathrm{RBF} / \mathrm{LBF}$ can be a simple alternative.

In India, RBF wells have been installed on the banks of many rivers/lakes in the past four decades. However, due to rapid industrialisation, urbanisation, population growth and insufficient wastewater collection/treatment facilities, rivers/lakes are increasingly getting polluted with ever expanding number of pollutants. RBF/LBF facilities are now facing challenges due to increasing levels and wider variety of pollutants. This has resulted in unaccepted quality of filtrate at Mathura [6] and Delhi [7] and closure of one of the RBF wells at Delhi [8]. Cosovic et al. [9] conducted a study on the polluted Gorjak stream, a tributary of the Sava river in Croatia. The Chemical Oxygen Demand (COD) of the river water and water from RBF well were found to range from $870-5,330 \mathrm{mg} / \mathrm{L}$ and 3-5 mg/L respectively. The organics in well water were identified as fulvic and humic substances. Miettinen et al. [10] showed that high molecular weight organic fraction of the water of Lake Kallavesi, Finland, was reduced during RBF. The performance of an RBF system on polluted river Kali, in southern India was studied by Cady [11] and Cady et al. [12]. Results showed $88 \%$ to more than $99 \%$ removal of bacteria in the RBF well water. Concentrations of heavy metals were also found to decrease during RBF. In cases where $\mathrm{RBF} / \mathrm{LBF}$ wells are situated by the side of polluted source waters, data on water quality of bank filtrate is lacking. In such situations, further treatment appears necessary. It is very relevant as filtrate is utilized for drinking.

Detection of Organic Micropollutants (OMPs) in the surface waters has raised the interest to evaluate the fate of OMPs during RBF/LBF. Heberer et al. [13] and Verstraeten et al. [14] have reported the presence of many OMPs mainly pharmaceuticals, pesticides and industrial chemicals in the bank filtrate. Polar contaminants such as pharmaceuticals, pesticides, etc. leach into the groundwater while non-polar ones such as hormones, synthetic musk compounds, etc. are adsorbed in the aquifer and thus do not leach and appear in drinking water [15]. Scheytt et al. [16] and 
Maeng et al. [17] have shown that in RBF system, many of the OMPs degraded/removed but carbamazepine showed resistance. In river waters, pharmaceuticals, endocrine disrupting chemicals and personal care products, etc. are all present simultaneously. The fate of pollutants when present as a mixture is not very well understood.

Till 2010, globally RBF schemes were successfully implemented in the plains. Dash et al. [18] carried out studies at a LBF site located in land slide debris at an elevation of 1,937 $\mathrm{m}$ above mean sea level. Due to the presence of multiple faults, the site had a very complex hydrogeology. Results indicated that water of Lake Nainital was not potable as such. However, coliform bacteria were not detected in any of the filtrate samples collected from tube wells having depths from 26-36 m. Dash et al. [19] also studied some of the small devices, Koop wells, located in mountains about 2-3 m below the river bed for the collection of filtered river waters. Systems have been found to be very effective in removing turbidity and to some extent organics and coliforms too. In the mountainous regions, alluvial aquifers are narrow and restricted to the riverbanks. Also, banks have much higher variability in their composition (usually have a significant amount of coarse grains) than in the plains. In mountainous regions of India, particularly Himalayas, river/lake waters are cleaner in terms of organics and coliforms [20]. However, turbidity varies widely from non-monsoon to monsoon seasons. As little literature existed about the use of RBF in mountainous regions, it was also felt necessary to explore the possibility of the use of RBF in mountainous regions as an alternative of direct pumping of water for water supply.

With goals to develop RBF as a sustainable technology in India for providing safe drinking water, eight RBF schemes (Haridwar, Mathura, Delhi, Nainital, Srinagar, Satpuli, Agastmuni, Karnaprayag) have been studied over the last 10 years. Schemes covered:

- Diverse geological settings/regions, i.e. plains to mountains;

- Widely varying surface water quality, i.e. clean to contaminated;

- Dissimilar surface water sources, i.e. rivers to lakes;

- Different filtering media, i.e. bank to bed;

- Many types of well configurations, i.e. vertical, large diameter open-bottom and radial.

\section{MATERIALS AND METHODS}

Relevant details of the eight BF sites are given in the next section along with the results and discussion. Water samples from the rivers, lake, and the corresponding bank filtration wells were transported to the Environmental Engineering Laboratory, Department of Civil Engineering, IIT Roorkee and analysed for turbidity, major ions, Total Organic Carbon (TOC), Dissolved Organic Carbon (DOC), UV-absorbance, nitrate nitrogen, and Most Probable Number (MPN) of total and fecal coliform following the procedures laid down in the Standard Methods for the Examination of Water and Wastewater [21]. DOC concentrations were determined using a TOC-V CSN Total Organic Carbon Analyzer (Shimadzu). UV-absorbance at $254 \mathrm{~nm}$ was measured using a Hach DR/4000U Spectrophotometer. A Hach 2100 AN turbidity meter was used to measure turbidity. Major ions were analysed by an 861 Advanced Compact Ion Chromatograph (Metrohm). Specific UV-absorbance (SUVA) was calculated as the ratio of UV-254 $(1 / \mathrm{m})$ to DOC $(\mathrm{mg} / \mathrm{L})$. MPN of total and fecal coliforms were measured using multiple tube fermentation method. Stable isotopes $\left(\delta^{18} \mathrm{O}\right.$ and $\left.\delta^{2} \mathrm{H}\right)$ were determined using a dual inlet isotope ratio mass spectrometer (GV Instruments, Isoprime) at National Institute of Hydrology, Roorkee. For the determination OMPs water samples (1 L each) from Delhi RBF site were filtered through Glass Fiber Filters (GFF). The OMPs in the samples were extracted using Solid Phase Extraction (SPE) cartridges (Bond ElutPlexa, 
$200 \mathrm{mg}, 6 \mathrm{~mL}$, Agilent Technologies, India). The trace organics were quantified by a calibration curve method for each sample. Gas Chromatographic separation coupled with Mass Spectrometry (GC-MS) analysis was performed using Varian 450 GC 240 MS equipped with a split/splitless injector 1079 .

\section{RESULTS AND DISCUSSIONS}

Results have been discussed site wise. It includes relevant details of RBF sites, well type, hydrogeology, quality of source water and attenuation during RBF. In the end, total and fecal coliforms in river or lake water and production well water have been compared for different RBF sites studied.

\section{Haridwar}

Haridwar, a medium size town of religious importance in the Uttarakhand state of India has a large inflow of visitors round the year. Ground water, as well as riverbank filtrate, is supplied for domestic use. Sub-surface water, which is in direct connectivity with the river Ganga, is abstracted through twenty two 10-m diameter, shallow caisson wells located at distances ranging from 4 to $250 \mathrm{~m}$ from the bank of the river Ganga (Figure 1) [22]. River water contains turbidity. Water from production wells generally does not contain turbidity [23]. At Haridwar, the river water is contaminated with total coliform $(160-930,000 / 100 \mathrm{~mL})$ and fecal coliform $(160-24,000 / 100 \mathrm{~mL})$. Water from the production wells generally does not respond to MPN test (Figure 2). Disinfection is practiced to maintain residual chlorine in water supply system. Based on water quality analysis, production wells have been categorized into north and south wells with reference to the new supply channel [24]. The concentration of major ions in water from south wells is close to that of river water. However, water from wells in the North were found to have Calcium $(\mathrm{Ca})$, Magnesium $(\mathrm{Mg})$, Sodium $(\mathrm{Na})$ and alkalinity 3.2 to 5.5 times the concentration in the river water. Sulfate and chloride were respectively around 1.7 and 11.8 times more than the river water.

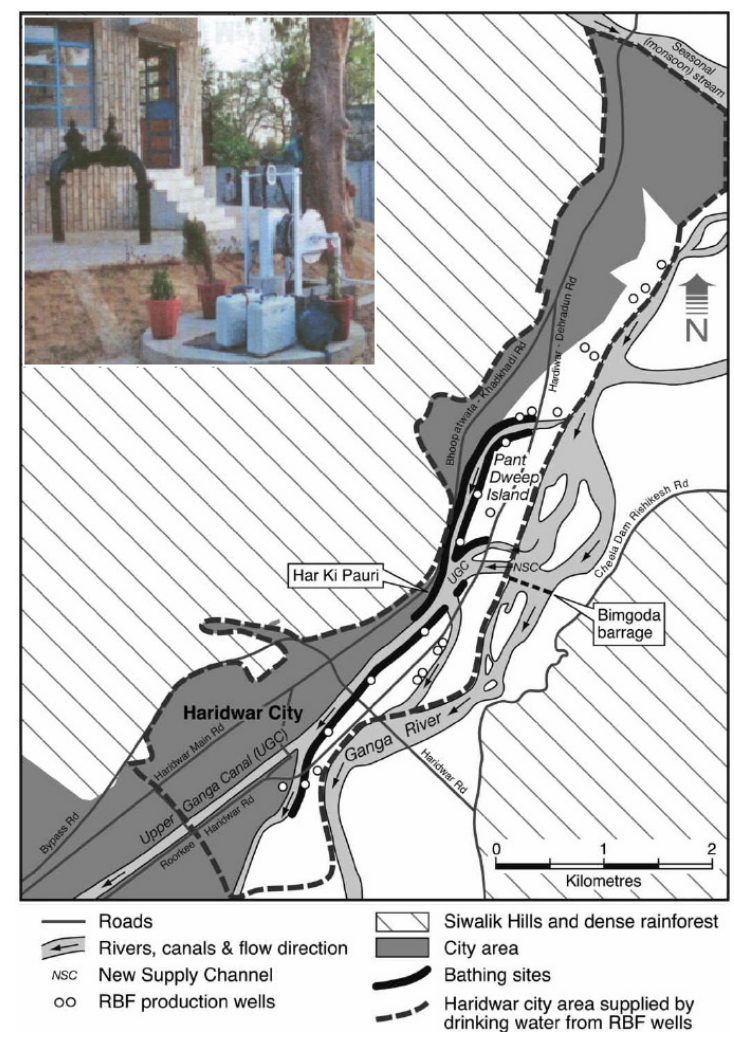

Figure 1. Production wells and watercourses at Haridwar (modified from [23]) 


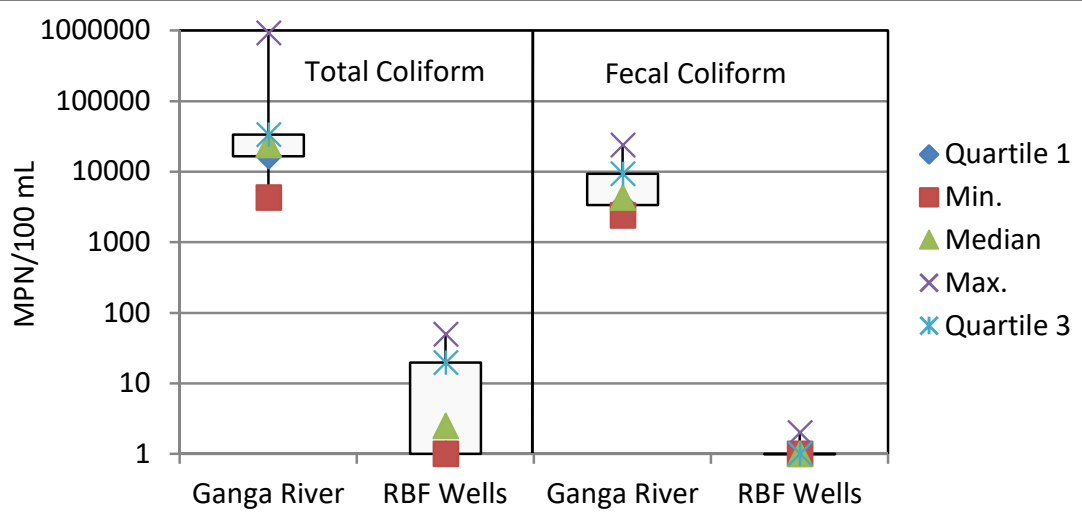

Figure 2. River Ganga and RBF wells: Box-plots for total and fecal coliform

\section{Nainital}

A LBF scheme comprising of nine tube wells on the bank of the lake Naini in Nainital, India exists in landslide debris (Figure 3) while most bank filtration sites globally are in alluvial aquifers. Bank material contains large pebbles, sand, and some clay. The water quality and stable isotopes $\left(\delta^{18} \mathrm{O}\right.$ and $\left.\delta^{2} \mathrm{H}\right)$ have been studied to assess the proportions of bank filtrate drawn by the wells. Results show that of the nine wells, two wells perennially abstract mainly bank filtrate, three abstract predominantly bank filtrate during non-monsoon but groundwater during monsoon and four wells mostly abstract ground water perennially [25]. Bank filtrate proportion in a well is not dependent on its distance from the lake. Also, more than one groundwater stream appears to be contributing to the well field. Such anomalous hydrology is likely due to hydro geological heterogeneity in the landslide debris or drainage from fractures and faults in the underlying geology. Travel time ranged from 1 to 19 days. The coliform load in lake water varied from 50-500,000 in monsoon and 46,000-240,000 MPN/100 mL in non-monsoon (Figure 4). But bank filtrate rarely showed any coliform even in the closest well located at a distance of $21 \mathrm{~m}$. Bank filtrate, when compared with lake water, showed 5.2 and $4.2 \log$ removals of total and fecal coliforms [26]. The study indicates that an LBF well in a landslide deposit can sustainably deliver water of drinking quality at a short distance of $\sim 5 \mathrm{~m}$ and travel time of $\sim 2-3$ days from the lake.

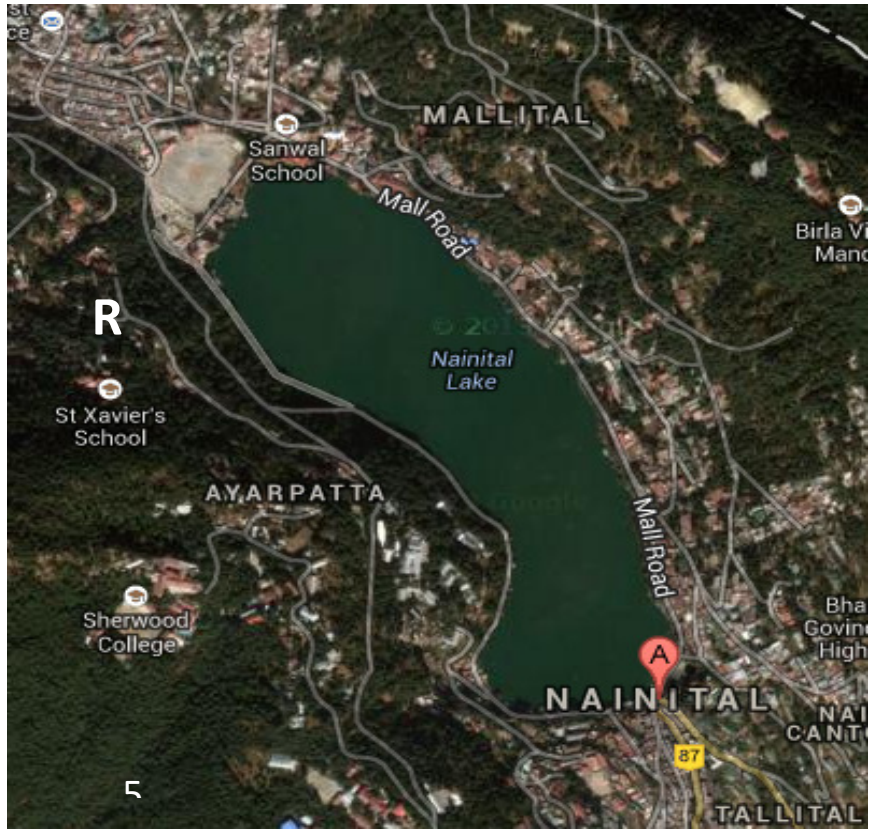

Figure 3. Google map of lake Nainital and RBF wells at Nainital 


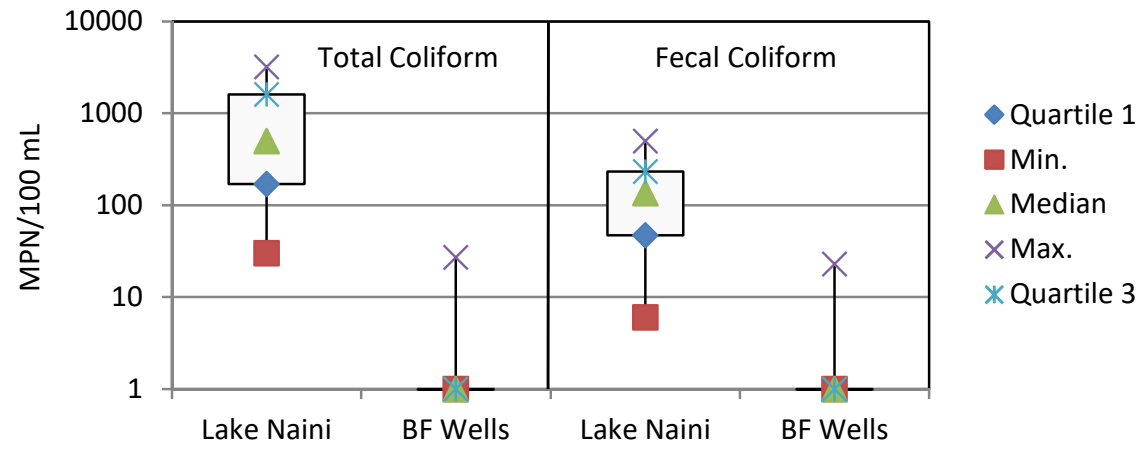

Figure 4. Lake Nainital and RBF wells: Box-plots for total and fecal coliform

\section{Mathura}

At Mathura, the Yamuna river contains bacterial load as well as organic pollution measured as TOC. Part of the Mathura water supply is comprised of the sub-surface water, which is collected from a radial well (Figure 5) placed in the middle of the riverbed having thirteen radials located entirely beneath the bed in two layers at 15.5 to $18 \mathrm{~m}$ [27]. Yamuna river had total coliform load ranging from 2,300 to 1,500,000 MPN/100 mL in different seasons. Coliform reduced to 43 to 75,000 (a reduction of $\sim 2$ logs) after passing through bed material (Figure 6). The filtrate is treated and supplied. It is important to note that in spite of short travel time of 1.5-3 days, the abstraction of water through RBF resulted in overall advantages in terms of improved raw water quality, reduced degree of subsequent treatment (and its cost) and decreased health hazards due to disinfection by-products [28].

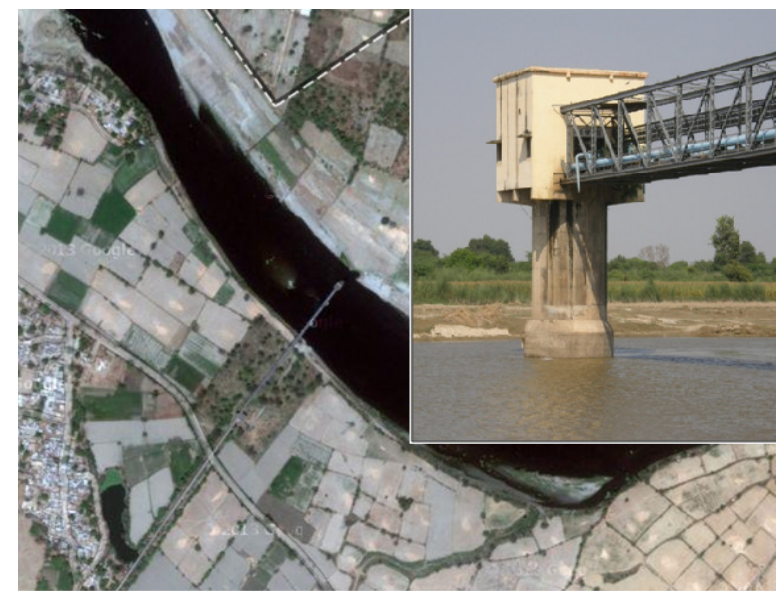

Figure 5. Google map of RBF site and radial well in river Yamuna at Mathura

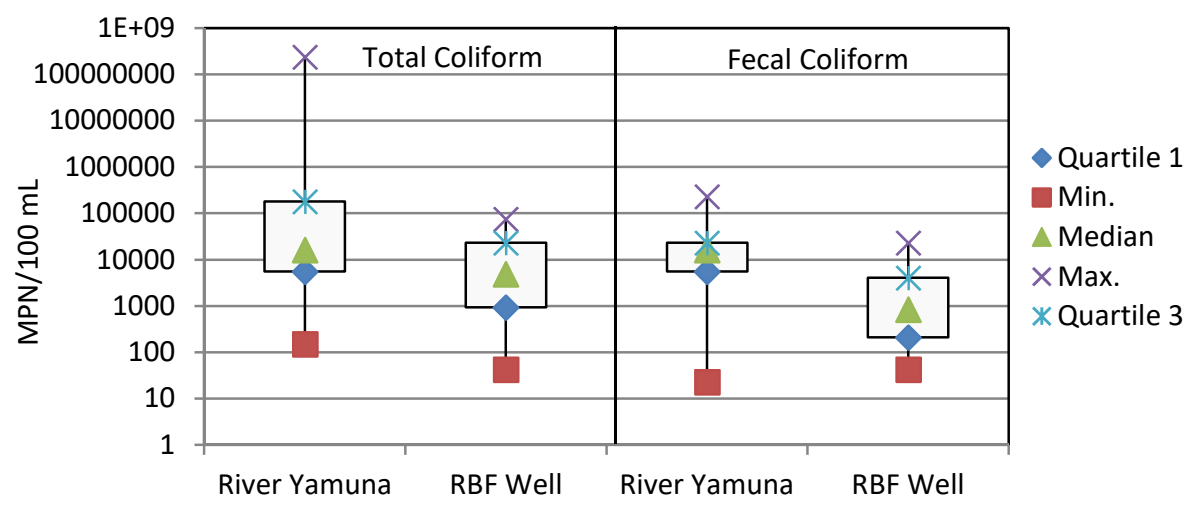

Figure 6. Box-plots for total and fecal coliform for river Yamuna and RBF well at Mathura 


\section{Delhi}

Water samples from the Yamuna river and eight Ranney Wells (RWs) near Akshardham temple in Delhi, India (Figure 7) were analysed in non-monsoon and the monsoon seasons [29]. The proportion of the bank filtrate drawn by the RWs was determined by monitoring $\delta^{18} \mathrm{O}$ and $\delta^{2} \mathrm{H}$, the stable isotopes of the water samples. The $\delta^{18} \mathrm{O}$ concentration of the river water in non-monsoon was significantly more than the monsoon water. The water from the wells in the monsoon was marginally lighter than the non-monsoon water. An attempt has been made to establish the hydraulic connectivity between the river and RW using $\delta^{18} \mathrm{O}$ data. Total coliform was reduced by more than 5 and $4 \log$ in non-monsoon and monsoon respectively. E-coli were reduced by more than $5 \operatorname{logs}$ in both the seasons (Figure 8). The organic pollution of the river was also reduced considerably. The average DOC of around $17 \mathrm{mg} / \mathrm{L}$ in the non-monsoon was reduced to around $2 \mathrm{mg} / \mathrm{L}$ in all the RWs except NR-I. Ultraviolet absorption at $254 \mathrm{~nm}$ (UV-254) and Specific UV absorbance (SUVA) followed the same trend as of DOC. Results suggest that in the case of contaminated source waters, RBF is an effective pre-treatment option for the production of drinking water. However, further treatment of filtrate is necessary.

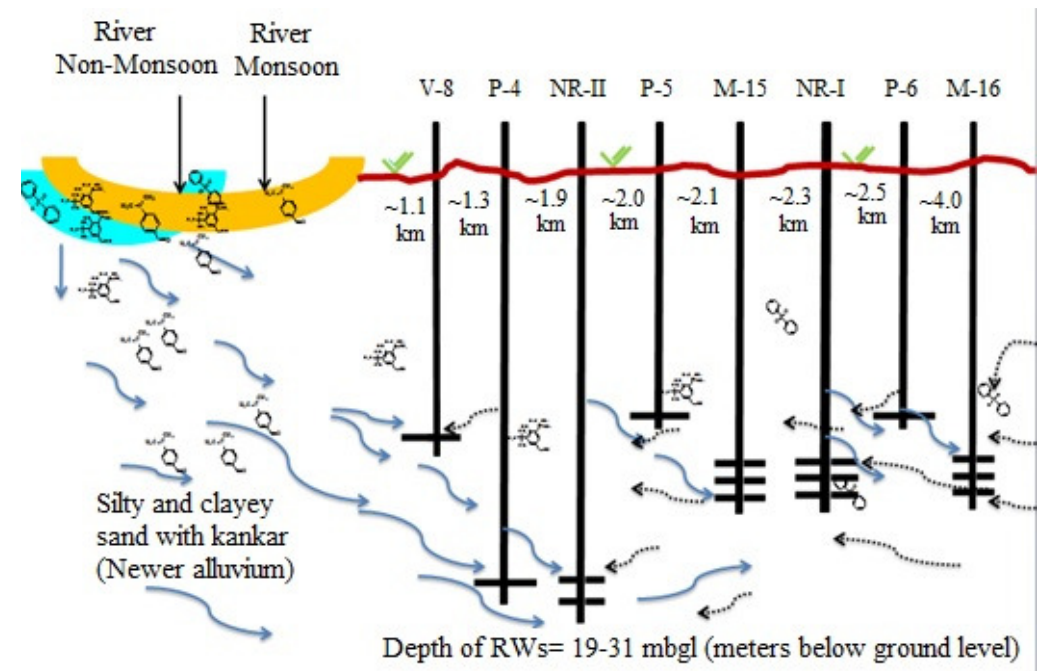

Figure 7. Conceptualized profile of the well field representing well numbers and their approximate distances from riverbank during non-monsoon [29]

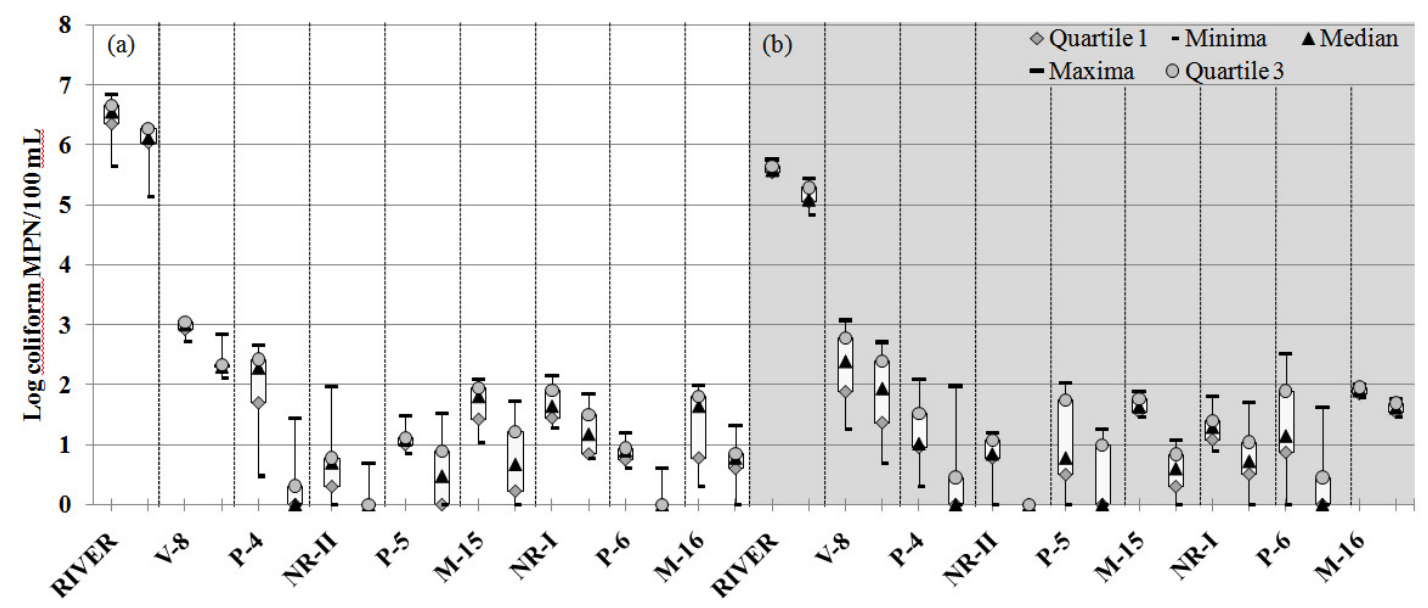

Figure 8. River Yamuna and Ranney wells: Total coliform and e-coli for: non-monsoon (a) and monsoon (b) (in each vertical column the first box-plot represents total coliform and the second one is for e-coli) [29] 
OMPs present in Yamuna river and eight RWs were also screened and quantified [29]. Fifty-seven detected OMPs in river Yamuna and RWs were identified as Pharmaceutically Active Compounds (PhACs), pesticides, Endocrine Disrupting Chemicals (EDCs), phthalates, Personal Care Products (PCPs), fatty acids, food additive, hormones and those organics present in hospital wastes in trace quantities. Number of OMPs detected, their frequencies of occurrence and concentrations in RWs reduced substantially compared to river water and correlated well with the distance of RWs from the river. Larger the distance, lesser the number of OMPs detected and lower their frequencies of occurrence and concentrations. In spite of significant levels $(\sim 50 \mu \mathrm{g} / \mathrm{L})$ in river water of 1-dodecanethiol, 3-acetamido-5-bromobenzoic acid, diethyl phthalate, palmitic acid and adenine, they were detected to be $<1 \mu \mathrm{g} / \mathrm{L}$ in RWs. Only a few OMPs e.g. simazine and aldrin, sometimes exceeded $1 \mu \mathrm{g} / \mathrm{L}$ in RWs. Compared to other OMPs, in general, EDCs, PCPs, phthalates, fatty acids and food additive appeared more frequently in the larger number of RWs. Among hormones, only estriol appeared once that too only in one of the RWs. Some of the OMPs e.g. adenine were never detected in any of the RWs.

\section{Srinagar, Kaleshwar, Agastmuni and Satpuli}

In 2010, four shallow vertical production wells (depth 18-30.3 m, diameter $125 \mathrm{~mm}$ ) were installed to assess the possibility and potential of RBF in the mountainous area of the Himalayas for water supply [30]. Wells were drilled on the banks of the rivers:

- Alaknanda in Srinagar and Kaleshwar;

- Eastern Nayar in Satpuli;

- Mandakini in Agastyamuni.

Elevations ranged from 551-769 $\mathrm{m}$ above mean sea level. Waters from the rivers, production wells and hand pumps were subsequently analyzed for major ions, turbidity, organics, coliforms and stable isotopes, $\delta^{18} \mathrm{O}$ and $\delta^{2} \mathrm{H}$.

The proportion of the riverbank filtrate was site specific and varied from monsoon to non-monsoon periods. The Satpuli scheme draws almost entirely bank filtrate round the year. The other three projects substantially abstract groundwater. In general, the bank filtrate proportion in the RBF wells in the sites studied decreased during the monsoon season and increased during the summer months. In Srinagar, the RBF well water was isotopically similar to the river water but chemically akin to the ground water. Travel time is in the range from 2 to 12 weeks.

The wells delivered turbidity-free water even during monsoon. Box plots of total coliform in the river (SW) and Production Well (PW) water samples for four mountainous RBF sites is given in Figure 9. Samples of water from production wells showed the presence of total coliforms once or twice in a year. However, fecal coliforms were not detected in any of the filtrate samples. In spite of high turbidity and bacterial load, bank filtration was found to be highly effective in bacterial and turbidity removal in the Himalayan region. In Srinagar, unusually high mineralization including nitrate contamination of the bank filtrate was observed [31]. Nitrate in the well water was more than $50 \mathrm{mg} / \mathrm{L}$. The RBF well waters in Satpuli, Agastyamuni, and Kaleshwar were of potable quality after chlorination. In Srinagar, the high nitrate concentrations problem could be addressed by mixing the RBF well water with water from conventional water treatment plant based on direct river water abstraction.

This analysis shows that RBF is a highly useful option for drinking water production in the Himalayan regions. The wells at the four sites had discharges comparable to other $\mathrm{RBF}$ locations in the world. A severe flooding event during the study period also did not change the water quality in the well, showing the resilience of RBF performance to such incidents. In general, the study shows RBF to be an efficient and sustainable option for the mountainous region such as the Himalayas. 


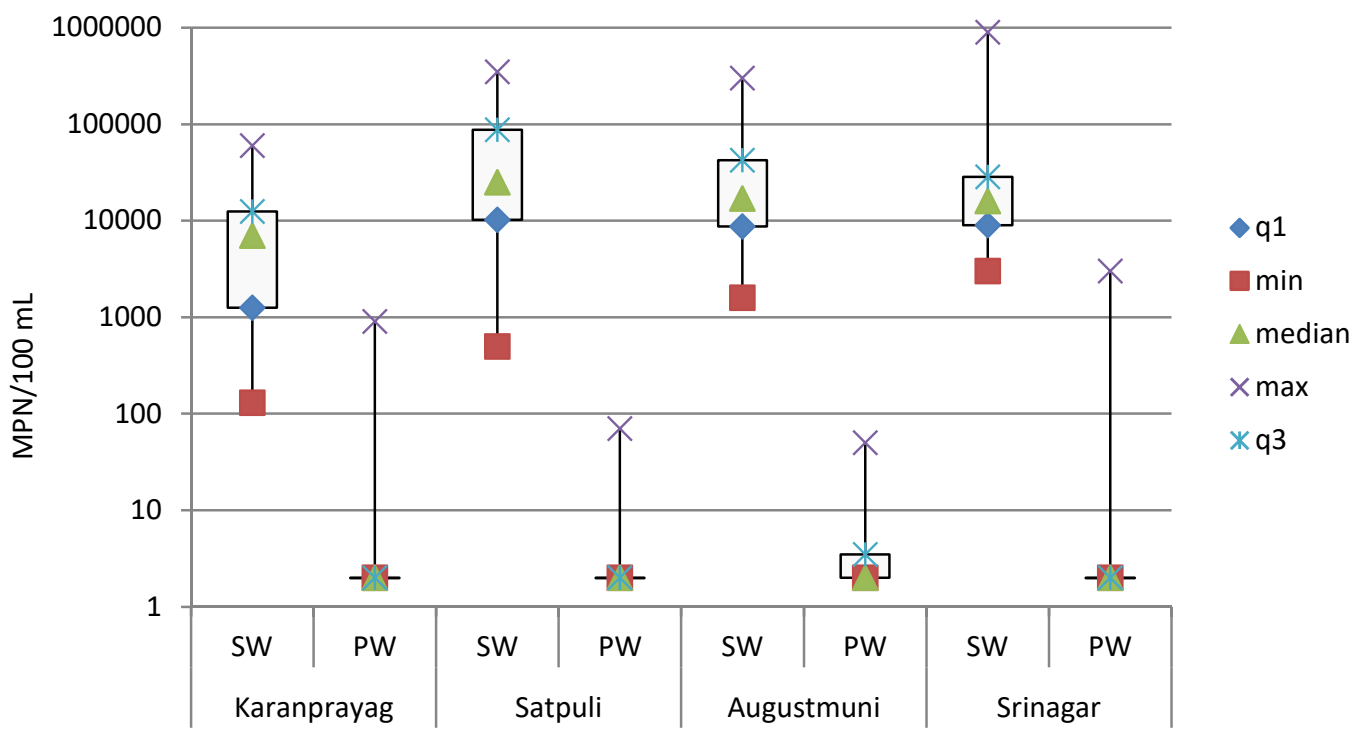

Figure 9. Box plots of total coliform in river (SW) and Production Well (PW) water samples for four mountainous RBF sites

\section{Comparison of total and fecal coliform at different riverbank filtration sites in India}

The range of values of total and fecal coliform for source water and filtrate for different RBF sites is shown in Table 1. Study over several sites indicates that bank filtration significantly reduces turbidity, coliforms, and TOC in the river/lake water. If the river water is not highly polluted, then bank filtration leads to complete removal of pathogens and thereby reduces health risk directly due to pathogens and indirectly due to Disinfection By- Products (DBPs) (Haridwar, Nainital, Srinagar, Satpuli, Agastmuni and Karnaprayag). RBF provides partial treatment to water from polluted rivers and reduces the overall cost of the treatment (Mathura and Delhi).

Table 1. Different RBF/LBF sites: Range of values of total and fecal coliform for source waters and filtrates

\begin{tabular}{cccccc}
\hline \multirow{2}{*}{$\begin{array}{c}\text { River/lake bank } \\
\text { filtration site }\end{array}$} & Period of study & \multicolumn{2}{c}{ Fecal coliform [MPN/100 mL] } & \multicolumn{2}{c}{ Total coliform [MPN/100 mL] } \\
\cline { 2 - 6 } & River/lake & Production well & River/lake & Production well \\
\hline Haridwar & $2005-2011$ & $1.6 \times 10^{2}-2.4 \times 10^{4}$ & $<2-9 \times 10^{1}$ & $1.6 \times 10^{2}-9.3 \times 10^{5}$ & $<2-1.7 \times 10^{2}$ \\
Nainital & $1997-2013$ & $5 \times 10^{1}-5 \times 10^{4}$ & $<2$ & $5 \times 10^{1}-5 \times 10^{5}$ & $<2$ \\
Kaleshwar & $2011-2013$ & $8 \times 10^{1}-1.3 \times 10^{4}$ & $<2$ & $1.3 \times 10^{2}-6 \times 10^{4}$ & $<2-9 \times 10^{2}$ \\
Satpuli & $2011-2013$ & $5 \times 10^{1}-9 \times 10^{4}$ & $<2$ & $5 \times 10^{2}-3.5 \times 10^{5}$ & $<2-7 \times 10^{1}$ \\
Agustmuni & $2011-2013$ & $9 \times 10^{2}-5 \times 10^{4}$ & $<2$ & $1.6 \times 10^{3}-3 \times 10^{5}$ & $<2-5 \times 10^{1}$ \\
Srinagar & $2011-2013$ & $8 \times 10^{2}-3 \times 10^{5}$ & $<2$ & $3 \times 10^{3}-9 \times 10^{5}$ & $<2-3 \times 10^{3}$ \\
Mathura & $2006-2008$ & $1.5 \times 10^{2}-2.3 \times 10^{5}$ & $43-9.3 \times 10^{3}$ & $2.3 \times 10^{3}-1.5 \times 10^{6}$ & $43-7.5 \times 10^{4}$ \\
Delhi & $2013-2014$ & $7 \times 10^{4}-2 \times 10^{6}$ & $<2-6.9 \times 10^{2}$ & $3 \times 10^{5}-7 \times 10^{6}$ & $<2-1.2 \times 10^{3}$ \\
\hline
\end{tabular}

\section{CONCLUSION}

The study shows that:

- $\mathrm{RBF}$ is an equally effective option for the production of drinking water both in case of a river and a lake;

- It has potential in augmenting water supply schemes at higher altitude too. Based on the success and lessons learnt during the current study, new RBF schemes have

\footnotetext{
$\dagger$ Occurrence of fecal coliforms in well water was once or twice in 10-15 samples

\# Occurrence of total coliforms in well water was once or twice in 10-15 samples
} 
been commissioned recently or are currently being installed in many hilly towns e.g. Karanprayag, Gauchar, Bageshwar, Kapkot, Uttarkashi, Srinagar, Agastmuni etc. These schemes utilize either large diameter production wells or tube wells;

- In case of polluted rivers too, RBF has some advantages as it acts as pre-treatment resulting in reduction of load on further treatment processes;

- RBF works well in case of all well configurations i.e., vertical, horizontal, radial, dug well;

- As effectiveness depends on travel time, attenuation of contaminants in case of bed filtration is limited.

\section{ACKNOWLEDGEMENT}

The authors are thankful to Ph.D. and M.Tech. students: Dr. Medalson Ronghang, Dr. R. R. Dash, Ms. Bharti Saini, Mr. Sandeep C., Mr. Himansu Singh, Mr. E. V. R. Bhanu Prakash and Ms. Preeti Singh. The authors are also grateful for the financial support for the project "Saph Pani - Enhancement of natural water systems and treatment methods for safe and sustainable water supply in India" by the European Commission (Grant Agreement No. 282911) and the project "Development of Riverbank Filtration in Hill-Regions for Sustainable Quality and Quantity of Drinking Water in Uttarakhand" for the construction of the RBF well within the "Water Technology Initiative" of the Department of Science and Technology (DSTWTI), Government of India.

\section{REFERENCES}

1. Kuehn, W. and Mueller, U., Riverbank Filtration: An Overview, Journal American Water Works Association, Vol. 92, No. 12, pp 60-69, 2000.

2. Ray, C., Melin, G. and Linsky, R. B., Riverbank Filtration, Improving Source-Water Quality, Kluwer Academic Publishers, Berlin, Germany, 2003, https://doi.org/10.1007/0-306-48154-5

3. Ray, C., Grischek, T., Schubert, J., Wang, J. W. and Speth, T. F., A Perspective of Riverbank Filtration, Journal of American Water Works Association, Vol. 94, No. 4, pp 149-160, 2002.

4. Partinoudi, V. and Collins, M. R., Assessing RBF Reduction/Removal Mechanisms for Microbial and Organic DBP Precursors, Journal of American Water Works Association, Vol. 99, No. 12, pp 61-71, 2007.

5. Ray, C., Schubert, J., Linsky, R. B. and Melin, G., Riverbank Filtration - Improving Source-Water Quality (Ray, C., Melin, G. and Linsky, R. B., eds.), Kluwer Academic Publishers, Berlin, Germany, 2003, https://doi.org/10.1007/0-306-48154-5

6. Kumar, P., Mehrotra, I., Boernick, H., Schmalz, V., Worch, E., Schmidt, W. and Grischek, T., Riverbank Filtration: An Alternative to Pre-Chlorination, Journal of Indian Water Works Association, pp 50-58, 2002.

7. Sprenger, C., Lorenzen, G. and Pekdeger, A., Occurrence and Fate of Microbial Pathogen and Organic Trace Compounds at Riverbank Filtration Sites in Delhi, India, TECHNEAU Integrated Project: D, 5(6), http://www.techneau.org, [Accessed: 15-July-2015]

8. Saph Pani: Enhancement of Natural Water Systems and Treatment Methods for Safe and Sustainable Water Supply in India, D 1.1Database of Relevant Pollutants in Urban Areas and their Attenuation at RBF Sites, http://www.saphpani.eu/fileadmin/uploads/Administrator/Deliverables/D1_1_Database _of_relevant_pollutants.pdf, [Accessed: 10-January-2012]

9. Cosovic, B., Hrsak, D., Vojvodic, V. and Krznaric, D., Transformation of Organic Matter and Bank Filtration from a Polluted Stream, Water Res., Vol. 30, No. 12, pp 2921-2928, 1996, https://doi.org/10.1016/S0043-1354(96)00185-6 
10.Miettinen, I. T., Martikainen, P. J. and Vartiainen, T., Mutagenicity and amount of Chloroform after Chlorination of Bank Filtered Lake Water, Science of Total Environment, Vol. 215, No. 1-2, pp 9-17, 1998, https://doi.org/10.1016/S0048-9697(98)00010-2

11.Cady, P., A Riverbank Filtration Demonstration Project on the Kali River, Dandeli Karnataka, India, Dissertation, http://digitalcommons.uri.edu/cgi/viewcontent.cgi?artical=1068\&context=theses, [Accessed: 15-December-2015]

12.Cady, P., Boving, T. B., Choudri, B. S., Cording, A., Patil, K. and Reddy, V., Attenuation of Bacteria at Riverbank Filtration Site in Rural India, Water Environ Res., Vol. 85, No. 11, pp 2164-2174, 2013, https://doi.org/10.2175/106143013X13736496909428

13.Heberer, T., Mechlinski, A., Fanck, B., Knappe, A., Massmann, G., Pekdeger, A. and Fritz, B., Field Studies on the Fate and Transport of Pharmaceutical Residues in Bank Filtration, Ground Water Monitoring and Remediation, Vol. 24, No. 2, pp 70-77, 2004, https://doi.org/10.1111/j.1745-6592.2004.tb00714.x

14.Verstraeten, I., Heberer, T. and Scheytt, T., Occurrence, Characteristics, Transport, and Fate of Pesticides, Pharmaceuticals, Industrial Products, and Personal Care Products at Riverbank Filtration Sites (Ray, C., Melin, G. and Linsky, R., eds.), Springer Netherlands, pp 175-227, 2003, https://doi.org/10.1007/0-306-48154-5_10

15.Heberer, T., Occurrence, Fate and Removal of Pharmaceutical Residues in the Aquatic Environment: A Review of Recent Research Data, Toxicological Letters, Vol. 131, No. 1-2, pp 5-17, 2002.

16.Scheytt, T. J., Mersmann, P. and Heberer, T., Mobility of Pharmaceuticals Carbamazepine, Diclofenac, Ibuprofen, and Propyphenazone in Miscible-Displacement Experiments, Journal of Contaminant Hydrology, Vol. 83, No. 1-2, pp 53-69, 2006, https://doi.org/10.1016/j.jconhyd.2005.11.002

17.Maeng, S. K., Sharma, S. K., Abel, C. D. T., Magic-Knezev, A. and Amy, G. L., Role of Biodegradation in the Removal of Pharmaceutically Active Compounds with different Bulk Organic Matter Characteristics through managed Aquifer recharge: Batch and Column Studies, Water Research, Vol. 45, No. 16, pp 4722-4736, 2011, https://doi.org/10.1016/j.watres.2011.05.043

18.Dash, R. R., Mehrotra, I., Kumar, P. and Grischek, T., Lake Bank Filtration at Nainital, India: Water-Quality Evaluation, Hydrogeology Journal, Vol. 16, No. 6, pp 1089-1099, 2008, https://doi.org/10.1007/s10040-008-0295-0

19.Dash, R. R., Water Purification through Natural Filtration, Ph.D. Thesis, Department of Civil Engineering, Indian Institute of Technology Roorkee, Roorkee, India, 2011.

20.Dash, R. R., Mehrotra, I., Kumar, P. and Grischek, T., Study of Water Quality Improvements at a Riverbank Filtration Site along the Upper Course of the River Ganga, India, Desalination and Water Treatment, Vol. 54, No. 9, pp 2422-2431, 2015, https://doi.org/10.1080/19443994.2014.903863

21.APHA, AWWA, WEF, Standard Methods for the Examination of Water and Wastewater $\left(21^{\text {st }}\right.$ ed.), American Public Health Association/American Water Works Association/Water Environment Federation, Washington DC, USA, 2005.

22.Bartak, R., Page, D., Sandhu, C., Grischek, T., Saini, B., Mehrotra, I., Jain, C. K. and Ghosh, N. C., Application of Risk Based Assessment and Management to Riverbank Filtration Sites in India, Journal of Water and Health, Vol. 13, No. 1, pp 174-189, 2015, https://doi.org/10.2166/wh.2014.075

23.Dash, R. R., Bhanu Prakash, E. V. P., Kumar, P., Mehrotra, I., Sandhu, C. and Grischek, T., Riverbank Filtration in Haridwar, India: Removal of Turbidity, Organics and Bacteria, Hydrogeology Journal, Vol. 18, No. 4, pp 973-983, 2010, https://doi.org/10.1007/s10040-010-0574-4 
24.Saini, B., Mehrotra, I., Kumar, P. and Verma, R., Insight of Riverbank Filtration System at Haridwar for Enhancement of Drinking Water Quality, Int. J. Current Engineering and Technology, Vol. 3, No. 4, pp 1264-1270, 2013.

25.Gupta, A., Singh, H., Ahmed, F., Mehrotra, I., Kumar, P., Kumar, S., Grischek, T. and Sandhu, C., Lake Bank Filtration in Landslide Debris: Irregular Hydrology with Effective Filtration, Sustainable Water Resources Management, Vol. 1, No. 1, pp 15-26, 2015, https://doi.org/10.1007/s40899-015-0001-z

26.Gupta, A., Singh, H., Mehrotra, I., Kumar, P., Kumar, S., Grischek, T. and Sandhu, C., Lake Bank Filtration for Water Supply in Nainital, SaphPani-Enhancement of Natural Water Systems and Treatment Methods for Safe and Sustainable Water Supply in India (Wintgens, T., Nättorp, A., Lakshmanan, E. and Asolekar, S. R., eds.), IWA Publishing, pp 39-56, ISBN13: 9781780407104, London, UK, 2016.

27.Singh, P., Kumar, P., Mehrotra, I. and Grischek, T., Impact of Riverbank Filtration on Treatment of Polluted River Water, J. Environmental Management, Vol. 91, No. 5, pp 1055-1062, 2010, https://doi.org/10.1016/j.jenvman.2009.11.013

28.Nisha, L., Removal of Dissolved Organic Carbon (DOC) during Riverbank Filtration, Ph.D. Thesis, Dept. of Civil Eng., IITR, Roorkee, India, 2014.

29.Kumari, S., Organic Micropollutants in the River Yamuna and Ranny Wells in Central Delhi, Ph.D. Thesis, Dept. of Civil Eng., IITR, Roorkee, India, 2015.

30.Medalson, R., Efficacy of Riverbank Filtration in Hilly Area, Ph.D. Thesis, Dept. of Civil Eng., IITR, Roorkee, India, 2015.

31.Gupta, A., Ronghang, M., Kumar, P., Mehrotra, I., Kumar, S., Grischek, T., Sandhu, C. and Knoeller, K., Nitrate Contamination of Riverbank Filtrate at Srinagar, Uttarakhand, India: A Case of Geogenic Mineralization, Journal of Hydrology, Vol. 531, No. 3, pp 626-637, 2015, https://doi.org/10.1016/j.jhydrol.2015.10.065 